\title{
Contemporary Issues in Marketing
}



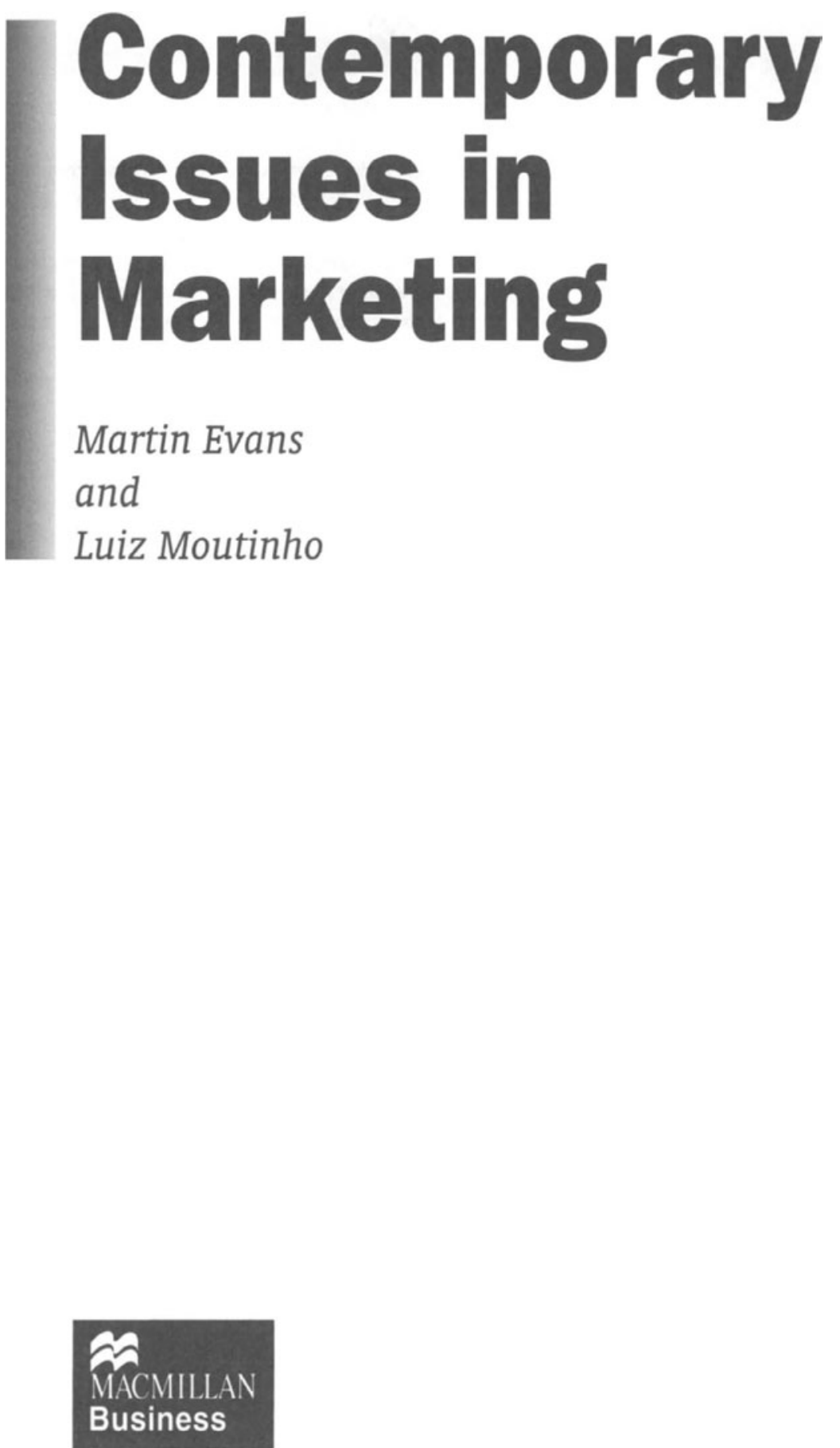
Selection and editorial matter@ Martin Evans and Luiz Moutinho 1999

All rights reserved. No reproduction, copy or transmission of this publication may be made without written permission.

No paragraph of this publication may be reproduced, copied or transmitted save with written permission or in accordance with the provisions of the Copyright, Designs and Patents Act 1988, or under the terms of any licence permitting limited copying issued by the Copyright Licensing Agency, 90 Tottenham Court Road, London W1P 9HE.

Any person who does any unauthorised act in relation to this publication may be liable to criminal prosecution and civil claims for damages.

The authors have asserted their rights to be identified as the authors of this work in accordance with the Copyright, Designs and Patents Act 1988.

First published 1999 by

MACMILLAN PRESS LTD

Houndmills, Basingstoke, Hampshire RG21 6XS

and London

Companies and representatives

throughout the world

ISBN 978-0-333-67774-2 ISBN 978-1-349-14299-6 (eBook)

DOI 10.1007/978-1-349-14299-6

A catalogue record for this book is available from the British Library.

This book is printed on paper suitable for recycling and made from fully managed and sustained forest sources

$\begin{array}{rrrrrrrrrr}10 & 9 & 8 & 7 & 6 & 5 & 4 & 3 & 2 & 1 \\ 08 & 07 & 06 & 05 & 04 & 03 & 02 & 01 & 00 & 99\end{array}$




\section{Contents}

Foreword

Preface

\section{Part 1 Issues in Market Analysis and Customer Behaviour}

\section{Introduction}

1 MARKETING ISSUE: THE MARKETING CONCEPT

Preparing a winning formula, Iain Murray, 4 November 1994, p. 90

A time for marketers to boldly go, Alan Mitchell, 6 October, 1995, pp. 28-9

2 THE MARKETING ENVIRONMENT

Ethical Consumerism

The power of ethical branding, Alan Mitchell, 22 May 1997 pp. 26-7

The Legal Environment

Utilities data taxes Labour, Sean Brierley, 17 April 1997, pp. 34-5

Direct Threat, David Reed, 29 May 1997, pp. 59-62

New data rules fail to smooth out flaws, David Benady, 7 August 1997, pp. 20-2

\section{CONSUMER BEHAVIOUR}

Use of Psychological Peripheral Cues

Psychological warfare, Helen Jones, 2 February 1996 pp. 32-5

Demographic Profiling

No longer simply a case of $\mathrm{ABC}$, Meg Carter, 18 March 1994, pp. 21-2

Lifestyle Profiles

The data game, David Reed, 3 May 1996, pp. 47-51
Facts of life,

Martin Croft, 1 May 1997, pp. 43-4

Marketing to the over 50s

Time pundits, Barbara Cummins, 8 April 1994, pp. 29-31

Pester Power

Kids take control of the trolleys, Meg Carter, 4 November 1994, pp. 21-2

Gender Segmentation

The good, the bad and the sexist, Barbara Nokes, 11 February, 1994, pp. 50-1

Calvin Klein makes 'offensive' ads pay, Jon Rees, 8 September 1995, p. 23

Who sits in the driving seat? John Clemens, 22 May 1997, pp. 28-9

Bare faced cheek of a naked butt, Iain Murray, 17 November 1995, p. 94

4 MARKETING RESEARCH AND INFORMATION

Survey Research

Flaw poll, Chris Boulding, 7 October 1994, pp. 36-9

Technology in Market Research

Time runs out on the meter, Torin Douglas, 21 January 1994, p. 15

Personalised Consumer Information 63

Tapping a valuable commodity, Alan Mitchell, 17 November 1995, pp. 28-9

Biographics

New model army,

David Reed, 14 July 1995, pp. 37-41

Knowledge is power,

David Reed, 8 December 1995, pp. 46-7 


\section{Contents}

\section{Part 2 Issues in Marketing Programmes}

Introduction

\section{PRODUCT POLICIES}

New Product Development

Unilever's NPD blues, Sean Brierley, 16 June 1995, pp. 40-3

\section{Packaging as a Marketing Tool}

The personal touch, Mary Lewis, 22 September 1995, pp. 52-3

\section{Brand Extension}

Testing out Virgin territory, Nick Higham, 4 November 1994, p. 19

\section{Retrospective Branding}

Respect for past masters, Alan Mitchell, 20 October 1995, pp. 30-1

\section{Niche Branding}

Time to shed a little tier or two, Alan Mitchell, 7 October 1994, pp. 28-9

\section{6}

\section{Low Pricing \\ Every day low pricing is a high-risk strategy, Andrew Scott, 22 March 1996, pp. 28-9}

\section{DISTRIBUTION}

\section{Channel Relationships \\ Grabbing a piece of the transaction, Alan Mitchell, 20 October 1995, pp. 30-1 \\ Matsushita plans own network to bypass \\ high-street retailers, 20 October 1995, p. 7 \\ A quest for successful relations, Alan Mitchell, 4 August 1995, pp. 26-7 \\ Retailing \\ Going shopping, European style Claire Murphy, 1 April, 1994, p. 20}

\section{Retail Loyalty}

Few benefits on the cards, David Benady and Sean Brierley, 5 July 5 1996, pp. 28-31
Benefit system,

David Reed, 12 January 1996, pp. 39-45

This year's model,

David Lazarus, 12 June 1997, pp. 53-7

8 MARKETING COMMUNICATIONS

\section{Selling 119}

Homing in on the mobile, Martin Croft, 10 November 1995, pp. 45-50

\section{Advertising: Fear Appeals}

Why shock ads have their place, John Shannon, 10 November 1995, p. 22

\section{Ethical Issues in PR}

A question of wealth interest, George Pitcher, 4 November 1994, p. 27

Promotion and Opinion Leader and Formers

Personality trade,

Yabba dabba dough!, Meg Carter, 22 July 1994, pp. 32-3

9 THE 'NEW' MARKETING

Database Analysis Jane Chipperfield, 11 March 1994, pp. 51-4 Jo-Anne Walker, 27 January 1995, pp. 49-51

Field Marketing

David Reed, 15 September 1995, 50-4

\section{Interactive Marketing 145}

Narrower targets come into sight, Graham Bednash, 30 September 1994, p. 14

A high street in every home, Meg Carter, 18 February 1994, pp. 20-1

Marketing on the Internet

Holes in the net,

Owners aboard, Nick Jones, 24 April, 1997, pp. 43-4

Safety net, David Reed, 21 August 1997, pp. 33-5
Web or dead, 
Part 3 Issues in Strategic Marketing Planning

Introduction

165

10 MARKETING ORGANISATION

Top brass fall for false economies, Alan Mitchell, 9 September 1994 pp. 28-9

11 DISTRIBUTION STRATEGY

Competitive Advantage in Distribution Channels

Bubble trouble, Sharon Marshall, 22 September 1995, pp. 38-9

12 BUSINESS TO BUSINESS MARKETING

Business to Business Approaches

Marketers learn to eat humble pie, Alan Mitchell, 22 September 1995, pp. 30-1

13 STRATEGIC INTEGRATION OF MARKETING COMMUNICATIONS

Mailshot in the arm, Helena Barton, 9 September 1994, pp. 49-51

The missing link, Lucy Killgren, 17 April 1997, pp. 53-4

Between the lines, Liz Stuart, 24 July 1997, pp. 32-3

14 GLOBAL MARKETING

European Marketing

PepsiCo unveils Euro strategy, Jon Rees, 30 September 1994, p. 8

Globalisation versus Customisation The name droppers, Helen Jones, 22 September 1995, pp. 36-7
166

166

170

170

170

173

173

173

177

177

179

181

184

184

184

187

187

15 EXTENDING THE MARKETING PARADIGM

191

Marketing Religion

191

Prepare to meet thy maker, Lindsay McMurdo and Helen Jones, 1 April 1994, pp. 30-3

Relationship Marketing

Swatch this space, Francesca Newland, 29 September 1995, pp. $78-80$

The secret of a good relationship, Alan Mitchell, 28 August 1997, pp. 20-1

One-to-One and differential marketing

Up close and personal, David Reed, 5 June 1997, pp. 41-6

The power of personal services, Alan Mitchell, 30 June 1995, pp. 30-1

Switching away from the masses, Alan Mitchell, 15 March 1996, pp. 34-5

16 STRATEGIC ISSUES

Marketing Alliances

209

Barclaycard runs rings round rivals, Sean Brierley, 22 March 1996, p. 22

Consumer Led Marketing Strategy 213

The last resort,

Pippa Considine, 15 September 1995, pp. 34-7

Strategic Advantage from Game Theory 217

Rules of the game theory,

Alan Mitchell, 28 October 1994, pp. 32-3

\section{Diversification Strategy 221}

Car makers switch into the finance lane, 221 Tom O'Sullivan, 11 August 1995, p. 17

References $\quad 224$

Index 


\section{Foreword}

As a young reporter on Marketing Week, I was once contacted by Anita Roddick, chief executive of the Body Shop. She was about to deliver a speech to the Marketing Society, but confessed to a small problem. No one she had asked was able to provide a succinct definition of the term 'marketing'. Could I help?

A facetious question, of course, from someone who was indisputably one of Britain's leading marketing practitioners. But it amply illustrates a point. Marketing is not just a set of pat definitions and abstract principles distilled into a business science. To succeed, the marketer needs much more: above all - like Roddick herself abundant energy, vision and purpose.

It is this realisation which has led to the publication of a new and very different kind of guide for would-be marketers: Contemporary Issues in Marketing by Martin Evans and Luiz Moutinho.
Quite properly, the book approaches marketing through a scholarly, logical schema. But it draws additional inspiration from the more haphazard reality of daily business life, as seen through the prism of our weekly news magazine.

That should give it, like any good new product development launch, a few advantages over the competition. First, it will be a more lively, approachable read, not least because it blends the everyday language of journalism with that of academe. Second, the juxtaposition of core text with news and features articles enhances the book's practical relevance for the many students who themselves aspire to be marketers.

Finally, I hope that this book will, in a modest way, convince new entrants to the world of marketing that our magazine is indispensable reading. 


\section{Preface}

Many courses in marketing are based on one of the major textbooks. No surprise there - that's why those books have been written! What we have produced in this volume is a collection of themed readings from the marketing press, which supplement and complement the core text.

Our own experiences of teaching marketing plus our and Macmillan's - research among other marketing teachers have revealed the need for a vehicle to put some of the textbook content into a highly recognisable and practical contemporary context. That is the idea behind this book, and we have been lucky to join forces with Marketing Week, one of the supplementary readers most recommended by marketing teachers. This book contains over 70 key articles ('clippings') from Marketing Week, covering some of the more significant developments and issues affecting contemporary marketing. Some of these issues are not always explored fully in the 'core textbook' format, so our intention is to fill this gap.

The book is divided into three parts covering three marketing themes: issues in market analysis and customer behaviour, issues in marketing programmes

and issues in strategic marketing planning. Within each is a collection of highly topical issues upon which to base seminar discussions, assignments and course work. In addition, the readings act as the context in which to apply concepts, theories other course materials.

For each issue we have provided some additional notes that delve further into the topic and in some cases reflect more recent research in that area. Most of the issues are covered by more than one clipping from Marketing Week to demonstrate either the multifaceted nature of the issue, or how its impact and implications 'moved on' in the period between the publication dates of the articles in question.

We hope you enjoy this book and that it helps to enrich your marketing course. We are also keen to receive your suggestions for improvement and hear what you like about the book. You can contact us via the publisher. Enjoy the clippings!

\section{Martin Evans}

University of the

West of England
LUIz MoUtinho

University of Glasgow 